\title{
Fiber Laser Based on Electronically Controlled Phase Plates
}

\author{
O.S. Hnatenko \\ Kharkiv National University of Radio Electronics, 14, Nauky Ave., 61166 Kharkiv, Ukraine
}

(Received 15 August 2021; revised manuscript received 20 October 2021; published online 25 October 2021)

\begin{abstract}
The physical principles of mode locking in fiber lasers for output radiation with a pulse duration of the femtosecond order have been studied. From the analysis performed, it can be concluded that the most effective method for the development of a ring fiber laser with ultrashort pulses is the method of nonlinear polarization evolution, which is characterized by simple settings for reaching the regime and stable mode locking. Short pulse durations were obtained by means of this method. A theoretical and experimental study of an LC cell for controlling laser polarization has been carried out. For nematic planar LC cells, there is cut-off voltage, which is $2.2-2.5 \mathrm{~V}$ for the cell described in this work. When studying the interaction of laser radiation with the cell, it was found that the angle of polarization state in space changes from 0 to $90^{\circ}$ when a voltage is applied from 2.2 to $10 \mathrm{~V}$. When a voltage of more than $10 \mathrm{~V}$ is applied, the cell is "saturated" and the angle of polarization rotation changes very little, and when a voltage of more than $10 \mathrm{~V}$ is applied, an electrical breakdown of the LC layer may occur. A theoretical simulation of mode locking in a ring fiber laser has been carried out. Namely, the formation of output laser pulses at different positions of the wave plates or voltage supply to the liquid crystal cell has been studied. Theoretically, the laser has the ability to generate both continuous and quasi-pulse modes. An experimental prototype of a fiber laser with mode locking by liquid crystal cells has been developed, which has the following parameters: pulse duration of the femtosecond order, radiation wavelength of $1550 \mathrm{~nm}$. These parameters give an advantage in the use of a laser for high-speed data transfer over fiber communication lines and quantum cryptography.
\end{abstract}

Keywords: Fiber laser, Optical fiber, Femtosecond, Polarization, Pulse duration, Amplitude, Frequency, Phase.

DOI: 10.21272/jnep.13(5).05038

PACS numbers: 42.55.Wd, 42.60.Fc

\section{INTRODUCTION}

Traditionally, fiber lasers with nonlinear evolution of polarization state (NEPS) have half-wave and quarter-wave plates in their designs [1,2]. These plates are designed to convert elliptical polarization of radiation into linear and vice versa, as well as to control the angle of rotation of linear polarization in space. It is a set of wave plates, together with a polarizing beam splitter (PBS), that provide the implementation of the NEPS method for the formation of ultrashort pulses in lasers of this type.

Most often, such a scheme uses three wave plates, a quarter-wave plate after the first collimator (in order to follow the course of radiation along the ring), which converts elliptically polarized radiation (through the ellipticity of the fiber) into linear polarization. Then the half-wave plate returns the linear polarization to the required angle in order to form the so-called saturating absorber together with the polarizing beam splitter.

Such an absorber will cut off the extreme low energy "wings" of the pulses and thus, each time passing through the resonator ring, a pulse, which is as short as possible, will be formed until the system is saturated, and radiation appears at the exit from the resonator with pulses of ultrashort duration.

But over time, the optical system of such lasers drifts and the NEPS mode gets lost; therefore, sometimes one more half-wave plate is introduced into the cavity after the PBS. Adjustment of the required orientation of the wave plates in this laser scheme is carried out manually or by expensive motorized drives by rotating these plates in space. Therefore, due to various external influences, it is often necessary to adjust the mode locking mode again. To get rid of this disad- vantage, it is proposed to use LC cells as polarization controllers (Fig. 1) [1, 2].

A combination of an LC cell with fixed quarter-wave plates is used to achieve the desired level of polarization control. LC cell No. 2 is optional and can be used for additional debugging, therefore, the work theoretically describes a circuit with one LC cell.

In this case, the LC polarizer replaces the half-wave plate. The quarter-wave plates required to enable the LC cell to operate are in a fixed position (without rotation).

But for the design and theoretical study of the laser circuit (Fig. 1), it is necessary to calculate certain parameters of optical fibers, the stability of polarization for mode locking, and to prove the possibility of using LC cells in this circuit.

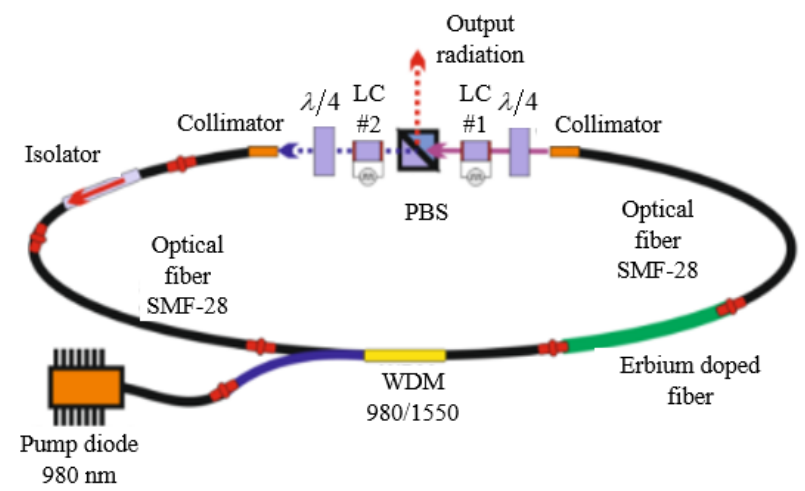

Fig. 1 - Typical diagram of a ring fiber laser with LC cells

\section{STUDYING LC CELLS}

In this work, we used LC cells based on a twist structure. Twist structures of nematic liquid crystal (NLC) 
are widely used in various display, communication devices and LC light modulators, due to the possibility of achieving higher speed and contrast with their help.

A diagram of the change in the orientation of LC molecules upon application of an electric field to the twist cell is shown in Fig. 2. The twist structure returns the polarization vector of light to an angle of $90^{\circ}$ and the light passes through the liquid crystal layer in crossed polarizers. When an electric field is applied to the cell, the director turns around and the transmission is weakened. When the director is in a vertical position $\left(\theta_{p}=90^{\circ}\right)$, light does not pass through this structure [3-8].

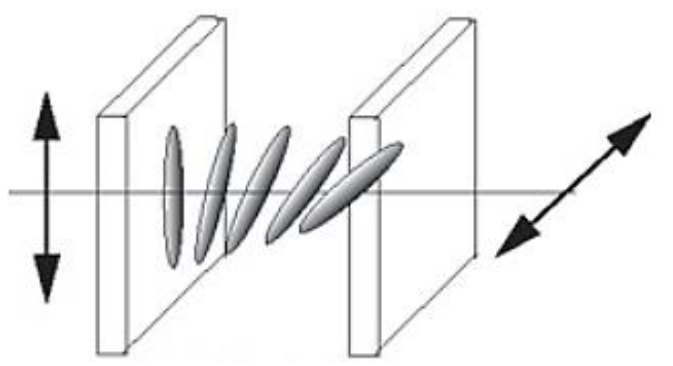

Fig. 2 - Diagram on the change in the orientation of LC molecules upon application of an electric field to a twist cell

In case the direction of the director on the front substrate of the LC cell, placed between the polarizer and the analyzer parallel to it, coincides with the axis of the polarizer, then the intensity of the light transmitted through the cell will be equal to [4]:

$$
I=\frac{\sin ^{2}\left(\varphi \sqrt{1+q^{2}}\right)}{1+q^{2}},
$$

where $\varphi$ is the twist angle, $q=\pi d \Delta n / \lambda \varphi$.

For $90^{\circ}$ twist effect, $\varphi=\pi / 2$. The transmission intensity $I$ is an oscillating function of the $d / \lambda$ parameter. If we assume that for the first minimum of the transmission curve $I=0$, when solving equation (1), then the minimum thickness of the LC layer at which the maximum contrast is achieved will be as follows:

$$
d_{\min }=\frac{\sqrt{3} \lambda}{2 \Delta n} .
$$

The change in the transmission intensity of the twist cell depending on the layer thickness is illustrated in Fig. 3. The minimum layer thickness of the LC cell must correspond to the first maximum transmission. We used LC cells manufactured by the Institute of Chemistry of New Materials of the National Academy of Sciences of Belarus. They provide for the $\Delta n \cong 0.21$ parameter, therefore, at $1.55 \mu \mathrm{m}$ wavelength, the minimum layer thickness to obtain maximum contrast must be greater than $6.4 \mu \mathrm{m}$. Fig. 4 shows a cell with $6.7 \mu \mathrm{m}$ layer thickness.

The transmission intensity decreases with a change in the twist angle of the twist structure in an electric field. The calculated dependence of the transmitted radiation intensity on the $\varphi$ twist angle is shown in Fig. 4.

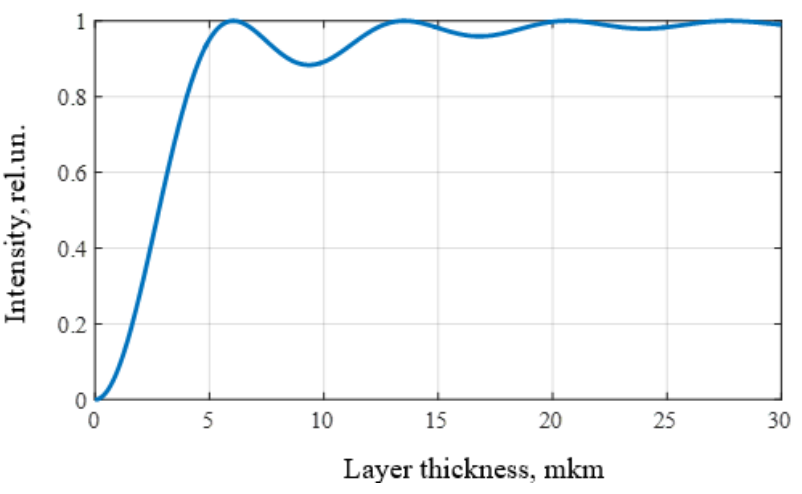

Fig. 3 - Dependence of intensity on the twist cell thickness for $1.55 \mu \mathrm{m}$ wavelength

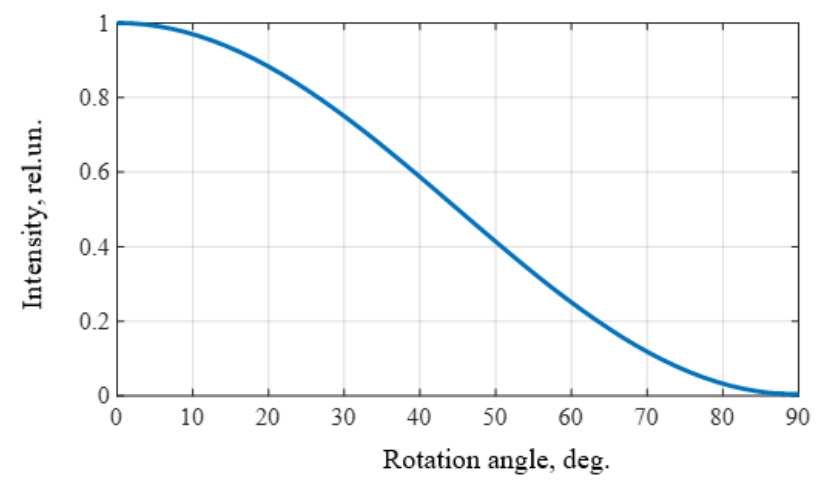

Fig. 4 - Dependence of the intensity of radiation that passed through the twist structure on the twist angle

The dependence of the transmission on the voltage for $90^{\circ}$ twist-cell is shown in Fig. 5. The voltage at which the decline in transmission to the twist cell begins, corresponds to the $U_{o p}$ optical threshold of the twist effect. In the voltage region $U_{t h}<U<U_{o p}$, the director of the LC begins to tilt, and the effective birefringence of the LC and the phase delay in the layer are reduced.

At a voltage exceeding the optical threshold, the angle of rotation of the polarization plane of linearly polarized radiation along the axis perpendicular to the layer changes in the twisted structure. This process is accompanied by a weakening of the transmission of the twist cell. At a voltage that significantly exceeds the optical threshold of the effect, when molecules in the central part of the LC layer are reoriented perpendicular to the electrodes, the twist structure ceases to rotate the light polarization plane, and the cell becomes opaque in crossed polarizers (Fig. 2).

When the voltage is removed, the molecules of the nematic LC return to their initial position under the action of elastic forces, and the twist cell begins to transmit the incident radiation again [9-12].

Fig. 5 shows an experimental study of the dependence of the transmission for the LC cell used in this work on the voltage applied to it $[1,2]$.

It can be seen from the curve that $U_{o p}=2 \mathrm{~V}$. In the region of voltages greater than $U>>10 \mathrm{~V}$, the director in the LC volume is completely reoriented at $\beta=0$ angle, that is, the operating voltage range does not exceed $10.5 \mathrm{~V}$ : for LC control, the operating voltage range should match $2 \mathrm{~V}$ to $10.5 \mathrm{~V}$. 


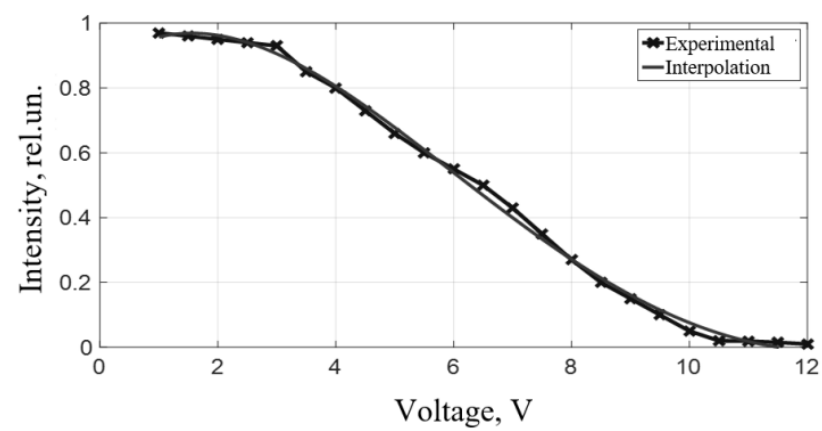

Fig. 5 - Experimental dependences of the attenuation of the transmission of radiation with $1.55 \mu \mathrm{m}$ wavelength by twist cells

For a theoretical study of the polarization control using an LC cell, the solution of the Oseen-Frank equation [1-7] is used:

$$
F=\int\left\{\frac{1}{2} K_{22}\left(\frac{d \theta}{d z}\right)^{2}-\frac{1}{2} \varepsilon_{0} \Delta \varepsilon E^{2} \sin ^{2}(\theta)\right\} .
$$

The solution to equation (3) is described in [1]. Using the mathematical model presented in [1] with the help of mathematical and numerical methods, one can study the electro-optical parameters of LC crystals for further use in ring goiter-window lasers as polarization controllers. Fig. 6 shows the theoretical and experimental curves of the dependence of the polarization rotation angle of the radiation on the voltage applied to the LC cell.

Fig. 6 shows that the dependence of the angle of polarization rotation on the voltage applied to the LC cell is nonlinear. For nematic planar LC cells, there is a cut-off voltage, which in this case is equal to $2.2-2.5 \mathrm{~V}$. From the theoretical curve it follows that the angle of polarization orientation in space changes from $0^{\circ}$ to $90^{\circ}$ at an applied voltage of $2.2 \mathrm{~V}$ up to $10 \mathrm{~V}$. When a voltage of more than $10 \mathrm{~V}$ is applied to the LC, the cell is "saturated" and the angle of polarization rotation changes very little, while when a voltage of more than $10 \mathrm{~V}$ is applied, an electrical breakdown of the LC layer may occur. The experimental curve practically coincides with the theoretical one; the reason for the minimum difference may be the error of measuring instruments or calculation methods (Fig. 6). In an experimental study, a voltage of various amplitudes (from 0 to $10 \mathrm{~V}$ ) was applied to the LC cell in the form of a meander with a frequency of $1 \mathrm{kHz}$.

With a fixed position of the quarter-wave plates relative to the axis of the LC cell, namely $78,88^{\circ}$, the maxima of the transmission of the radiation intensity through the optical axis when the voltage is applied to the LC cell will be 3.9, 7.1, $10 \mathrm{~V}$ (Fig. 7) [1, 2].

Thus, the performed studies prove that the LC cell can be used as polarization controllers for mode locking in fiber ring lasers.

When providing LC cells that can be used not only as half-wave plates, but also quarter-wave plates, for example like those produced by Thorlabs (Fig. 8), the laser circuit can include only LC cells for monitoring and mode locking (Fig. 9). The author of the work certified this idea by the patent for the invention UA 111309 .

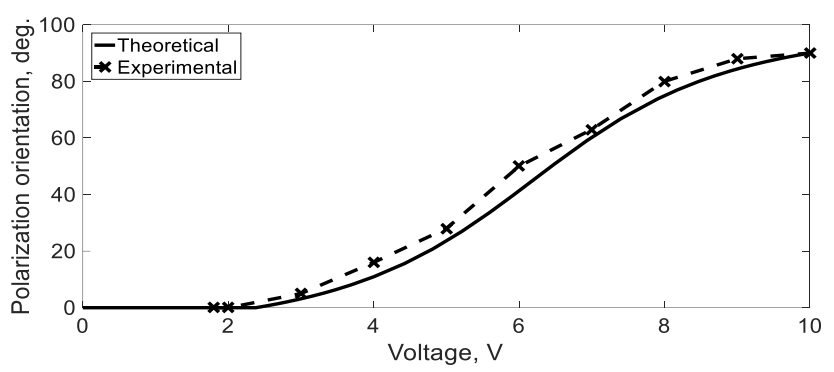

Fig. 6 - Dependence of the polarization rotation angle on the voltage applied to the $\mathrm{LC}$ cell

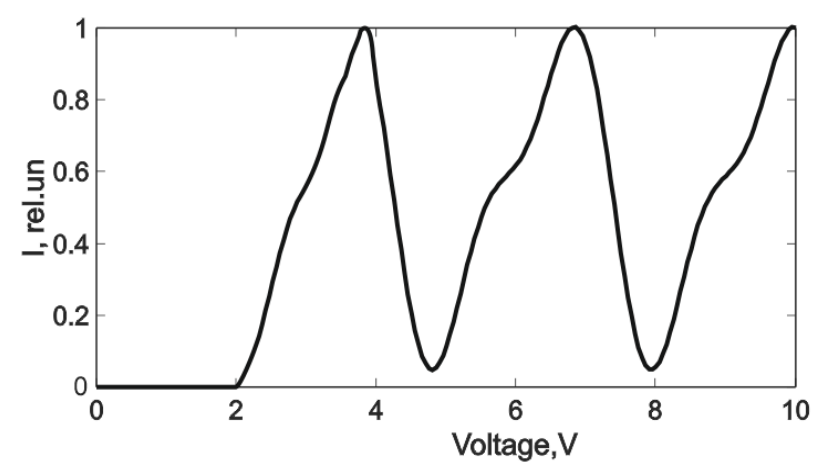

Fig. 7 - Dependence of the intensity of radiation passing through the laser optical system on the voltage applied to the LC cell

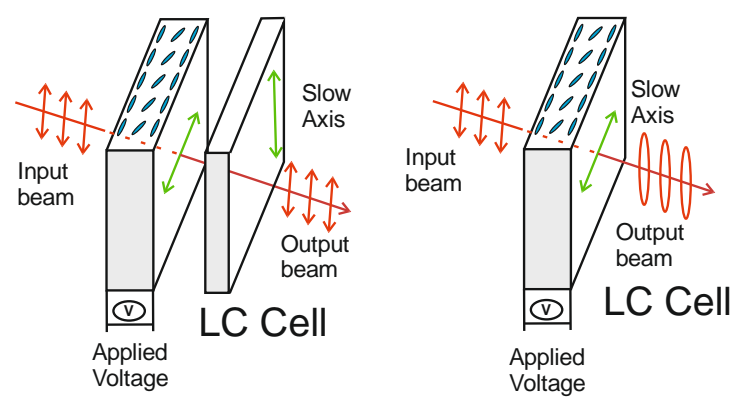

Fig. 8 - The operation principle of LC cells as both half-wave and quarter-wave plates (Thorlabs)

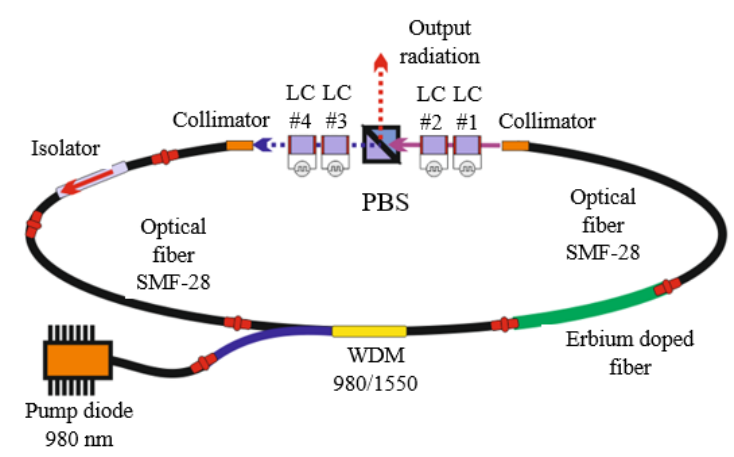

Fig. 9 - Diagram of a ring fiber laser using only LC polarizers

As a result, a theoretical and experimental study of LC cells for controlling the polarization of laser radiation was carried out. For nematic planar LC cells, there is a cutoff voltage, which in our case is 2.2-2.5 V. From the theoretical curve, we can conclude that the polarization angle in space changes from 0 to $90^{\circ}$ at an applied voltage of $2.2 \mathrm{~V}$ up to $10 \mathrm{~V}$. When a voltage of more than $10 \mathrm{~V}$ is applied, the LC cell "is saturated", and the angle of polarization rotation changes very little, while when 
a voltage of more than $10 \mathrm{~V}$ is applied, an electrical breakdown of the LC layer may occur.

\section{THEORETICAL STUDIES OF LASER OSCILLATION}

In order to simulate the formation of laser pulses, it is necessary to use the Ginzburg-Landau equation [1], in addition, it is necessary to take into account the temporal distribution, for this, first of all, we turn to dimensionless quantities [13-16]. In dimensionless variables, taking into account the time component of the solution of the equation, the Ginzburg-Landau equation for fiber lasers [1-2] takes the following form:

$$
\begin{aligned}
& A_{n+1}(\tau)=\kappa^{2} / 2\left[1-\sin \left(2\left(p I_{n}+\alpha_{1}\right)\right) \times\right. \\
& \sin (2 \theta)+i \cos \left(2\left(p I_{n}+\alpha_{1}\right)\right) \cos (2 \theta) \times \\
& \left.\times \cos \left(2\left(\alpha_{1}+\theta-2 \alpha_{2}+\Delta \varphi\right)\right)\right] A_{n}
\end{aligned}
$$

The change in the field amplitude during the passage of wave plates, an LC cell and a polarizing beam splitter, is described by equation (4). Thereafter, this changed field amplitude is used as the input solution to the equation for the same expression. To solve equation (4), the standard method of splitting by physical quantities (in this case, into nonlinear and dispersion components) was used using the fast Fourier transform [17-20]. Thus, after each pass of the laser cavity, the field amplitude was changed and used as the initial condition for equation (4). This process is repeated until the mode-locking regime is established and the field passing through the cavity is not changed. Fig. 10 shows the result of numerical simulation of laser mode locking in relative units [15].

Fig. 10 shows the formation with each pass of a shorter and shorter pulse, until the moment of complete mode locking, when the pulse amplitude becomes constant.

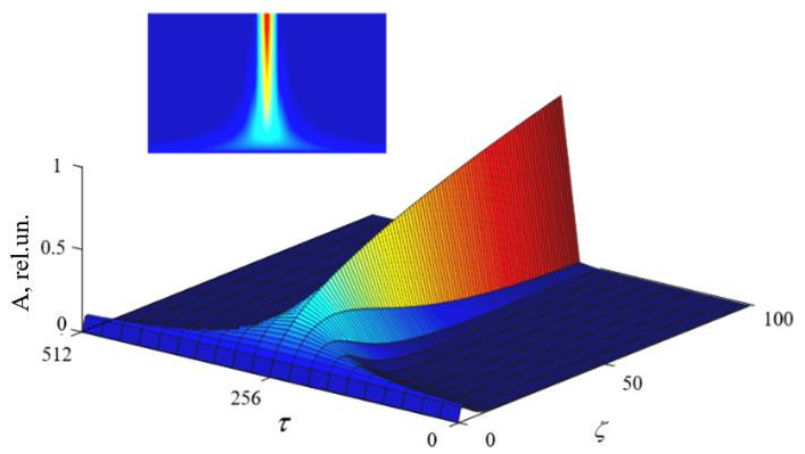

Fig. 10 - Dependence of the amplitude of the emulsions on the number of passes through the resonator $\zeta$ and the duration $\tau$ at $\alpha_{1}=78^{\circ}, \alpha_{2}=80^{\circ}, \theta=90^{\circ}$ or when applying $9.8 \mathrm{~V}$ voltage to the LC cell instead of a half-wave plate.

\section{PHYSICAL EMBODIMENT OF EXPERIMENTAL MODEL OF THE RING FIBER LASER}

\subsection{Pump Diode Control System}

The radiation power of the pump diode of the ring fi- ber laser is selected based on the conversion factor of the pump radiation to that generated by the fiber laser. In this case, the operating current of the pump laser was $518 \mathrm{~mA}$. Thus, the optimal indicators of the spectral characteristics of the diode being pumped were obtained at the maximum permissible current, namely $520 \mathrm{~mA}$, which corresponds to its passport data (Table 1).

The main operating parameters of the pump module (the table shows the main values of the parameters) must be equipped with an electronic control system. The main feature of the power supply of a semiconductor laser is the smooth voltage supply for several milliseconds. We used a semiconductor pump laser with fiber output in this work.

Table 1 - Electronic characteristics of the pump module

\begin{tabular}{|c|c|}
\hline Parameters & Values \\
\hline \multicolumn{2}{|c|}{ Pump diode } \\
\hline Direct current & $520 \mathrm{~mA}$ \\
\hline Direct voltage & $2 \mathrm{~V}$ \\
\hline \multicolumn{2}{|c|}{ Thermistor } \\
\hline \multicolumn{2}{|c|}{$10 \mathrm{kOhm}$} \\
\hline Resistance & $2.1 \mathrm{~V}$ \\
\hline Thermoelectric "cooler" \\
\hline Consumed voltage & $1.4 \mathrm{~A}$ \\
\hline Ponsumed current & $2.9 \mathrm{~W}$ \\
\hline
\end{tabular}

The external wiring on the laser body is butterfly type, which allows for quick connection of the laser to the control system. The driver was based on the NCP3065 microcircuit. Its main advantage is the smooth supply of voltage at the output, which is what is needed for a laser diode, so that it does not fail from a sudden power surge. Any spikes in the output voltage that negatively affect the laser diode are clipped at the rated output voltage. Thus, at the output, we have a pure level of nominal output voltage without surges and obstacles. The circuit also implements an output current tuning.

\subsection{Laser Thermostabilization System}

The laser thermal stabilization system is based on the MAX1968 microcircuit, which consists of two current regulators, which, working together, allow you to directly control the TEC current. This control configuration allows the current to be controlled to cool and heat the Peltier element at the same time, making it possible to control the TEC temperature, given the stringent requirements of the laser. The block diagram of the thermal stabilization system is shown in Fig. 11. The circuit is implemented using a thermistor, which is feedback related to the control of the TEC currents. Feedback is organized through a comparison circuit based on the MAX4477 and MAX4475 operating amplifiers. The stand was assembled with a load similar to laser diodes: a thermistor and a Peltier element according to the same parameters, which are implemented in the pump diode, in order to test the system. The result of testing during heating was the value of the stabilized laser temperature within $(25 \pm 0.5){ }^{\circ} \mathrm{C}$, which corresponds to the high efficiency and correct operation of this system. 


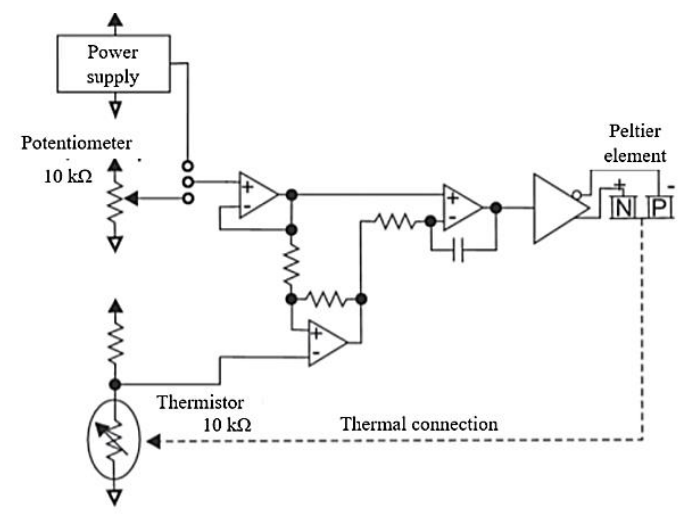

Fig. 11 - Peltier element control diagram

\subsection{LC Cell Control System}

In this work, LC cells are controlled by a rectangular signal with a frequency of $1 \mathrm{kHz}$ to $10 \mathrm{kHz}$ and an amplitude of 0 to $10 \mathrm{~V}$. One of the simplest and most versatile solutions of such a generator is the use of a NE555 microcircuit. NE555 is an analog integrated circuit, a universal timer - a device for generating (forming) single and repetitive pulses with stable time characteristics. The microcircuit is used to build various generators, modulators, time relays, threshold devices and other components of electronic equipment.

As examples of the use of a timer microcircuit, one can name the functions of restoring a digital signal distorted in communication lines, clang filters, on-off regulators in automatic control systems, pulse power converters, pulse-width control devices, timers, and others. The NE555 switching circuit in stable mode is shown in Fig. 12.

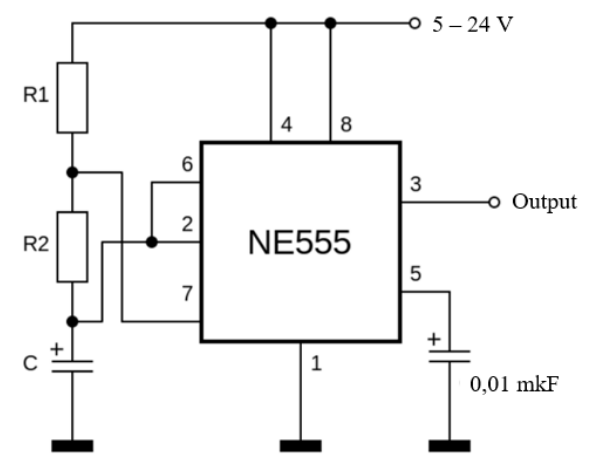

Fig. 12 - Diagram of NE555 switching

The repetition rate of rectangular pulses can be calculated using the formula:

$$
f=\frac{1}{0,693 C(R 1+2 R 2)},
$$

where the values of resistances $R 1$ and $R 2$ are substituted in Ohms, capacitance $C$ - in Farads, frequency $f$ in Hertz.

Thus, to generate rectangular pulses with a repetition rate of $1 \mathrm{kHz}$, the required parameters are: $R 1=$ $1 \mathrm{k} \Omega, C=100 \mathrm{nF}, R 2=6.7 \mathrm{k} \Omega$. To complete the task: create a generator with a variable frequency and signal amplitude (meander), potentiometers with a smooth adjustment at the output of the microcircuit were used, which makes it possible to adjust the signal amplitude from 0 to $10 \mathrm{~V}$ and a potentiometer instead of resistor $\mathrm{R} 2$ with a nominal value of $10 \mathrm{k} \Omega$, which makes it possible regulation of the pulse repetition rate in the range from $680 \mathrm{~Hz}$ to $14 \mathrm{kHz}$.

\section{CONCLUSIONS}

A theoretical and experimental study of LC cells for controlling the polarization of laser radiation was carried out in this work. There is a cutoff voltage, which in our case is equal to $2.2-2.5 \mathrm{~V}$, for nematic planar $\mathrm{LC}$ cells. We can conclude from the theoretical curve, that the polarization angle in space changes from 0 to $90^{\circ}$ with an applied voltage from 2.2 to $10 \mathrm{~V}$. When the voltage is more than $10 \mathrm{~V}$, the LC cell "is saturated" and the polarization rotation angle changes very little, while when a voltage of more than $10 \mathrm{~V}$ is applied, an electrical breakdown of the LC layer may occur. Based on the results of the work, a theoretical model of fiber laser mode locking with the help of liquid crystal cells was developed, which makes it possible to obtain the generation of ultrashort radiation pulses. The conditions for the stability of the polarization of longitudinal modes in a ring fiber laser using liquid crystal cells are studied experimentally.

The results of the study confirm the correctness of the constructed theoretical model and the efficiency of using liquid crystal cells as polarization controllers.

The paper also describes the implementation of a laser model and its main electronic modules: control of LC cells, control of a pump diode and its thermal stabilization.

The LC cell control module is based on the NE555 microcircuit and provides readjustment of the signal amplitude from 0 to $10 \mathrm{~V}$, as well as readjustment of the signal frequency from $680 \mathrm{~Hz}$ to $14 \mathrm{kHz}$.

When the pump laser was connected to the system of thermal stabilization and control of the pump current, the laser worked stably and gave out $330 \mathrm{~mW}$, which corresponds to its passport data; the measurement was carried out using an OPHIR power meter.

The laser diode pump current control system is universal, since by adding an external transistor to the circuit, currents up to $20 \mathrm{~A}$ can be developed, and if several NCP3065 microcircuits are connected in parallel, then it could be even more than 60 A. For example, for a pump current of $80 \mathrm{~A}$, they were connected in parallel to system 3 microcircuits. At the same time, the dimensions of the system increased due to the use of appropriate chokes and transistors for such currents, but the system worked flawlessly. The simplicity of implementation and efficient operation makes it possible to use the developed system to control the pumping of high-power semiconductor laser diodes, as well as all types of diode-pumped lasers.

When studying the output characteristics of a ring fiber laser, it was determined that the laser pulses have a high power, since the signal amplitude after the photodetector was hundreds of volts, while the receiver went into saturation mode. In this case, the average output power corresponds to a level of $20 \mathrm{~mW}$ with the passage of pulses with a frequency of $63 \mathrm{MHz}$. The pulse duration could not be measured due to the ab- 
sence of the autocorrelator, but judging by the oscillogram, it can be assumed that it is no more than ten picoseconds. Also, the work described indirect methods for measuring the duration of femtosecond-order pulses
- these methods are currently the main ones.

To create the laser described in this work were used $1 \mathrm{~m}$ of erbium-doped optical fiber and $3.3 \mathrm{~m}$ of SMF-28 optical fiber.

\section{REFERENCES}

1. A.S. Gnatenko, Yu.P Machekhin, Yu.S. Kurskoy, V.P. Obozna, J. Nano- Electron. Phys. 10 No 2, 02033 (2018).

2. A.S. Gnatenko, Yu.P. Machekhin, Yu.S. Kurskoy, V.P. Obozna, A.V. Vasianovych, Telecommun. Radio Eng. 77 No 6, 541 (2018).

3. I.V. Simdyankin, A.R. Geivandov, S.P. Palto, J. Exp. Theor. Phys. 131 No 4, 664 (2020).

4. A.G. Kalugin, Mechanics of Anisotropic Liquids (Publishing house of the Center for Applied Research at Mechanics and Mathematics. Faculty of Moscow State University: Russia: 2005).

5. E.A. Konshina, M.A. Fedorov, A.E. Rybnikova, L.P. Amosova, N.L. Ivanova, M.V. Isaev, D.S. Kostomarov, Tech. Phys. 54, 555 (2009).

6. O.E. Piro, G.A. Echeverria, F.D. Cukiernik, Crystallography Rev. 24 No 1, 3 (2018).

7. Yung-Hsun Wu, Yi-Hsin Lin, Yan-Qing Lu, Hongwen Ren, Yun-Hsing Fan, Janet R. Wu, Shin-Tson Wu, Opt. Exp. 12, 6382 (2004).

8. Haiying Wang, Thomas X. Wu, Xinyu Zhu, Shin-Tson Wu, J. Appl. Phys. 95 No 10, 5502 (2004).

9. J.L. Erickson, Trans. Soc. Rheol. 5, 23 (1961).
10. Yan-Qing Lu, Xiao Liang, Yung-Hsun Wu, Fang Du, ShinTson Wu, Appl. Phys. Lett. 85 No 16, 3354 (2004).

11. A.B. Golovin, S.V. Shiyanovskii, O.D. Lavrentovich, Appl. Phys. Lett. 83 No 19, 3864 (2003).

12. V.N. Vasil'ev, E.A. Konshina, M.A. Fedorov, L.P. Amosova, Tech. Phys. 55, 850 (2010).

13. Yu.P. Machekhin, Yu.S. Kurskoy, A.S. Gnatenko, V.A Tkachenko, Telecommun. Radio Eng. 77 No 13, 1179 (2018).

14. A.V. Vasyanovich, A.S. Gnatenko, D.V. Pustylnikov, Telecommun. Radio Eng. 77 No 19, 1685 (2018).

15. O.G. Okhotnikov, Fiber Lasers (Wiley VCH Verlag GmbH \& Co: KGaA: 2012).

16. O.O. Vakhnenko, Phys. Lett. A 405, 127431 (2021)

17. C. Heitzinger, C. Ringhofer, J. Comput. Electron. 3 No 1, 33 (2004).

18. G.M. Muslu, H.A. Erbay, Mathematics and Computers in Simulation (MATCOM) 67 No 6, 581 (2005).

19. L.A. Golovan, S.V. Zabotnov, Measurement of the Duration of Femtosecond Laser Pulses (Moscow: Yanus-K Publishing House: 2014).

20. T.A. Labutin, V.N. Lednev, A.A Ilyin, A.M. Popov, J. Anal. At. Spectrom. 31, 90 (2016).

\title{
Волоконний лазер на основі фазових пластин з електронним управлінням
}

\author{
О.С. Гнатенко
}

Харківський національний університет радіоелектроніки, пр. Науки, 14, 61166 Харків, Україна

Досліджено фізичні принципи синхронізації мод в волоконних лазерах для вихідного випромінювання з тривалістю імпульсу фемтосекундного порядку. 3 проведеного аналізу можна зробити висновок, що найбільш ефективним методом створення кільцевого волоконного лазера з ультракороткими імпульсами е метод еволюції нелінійної поляризації, який характеризуеться простими налаштуваннями виходу на режим і його стійкістю. Проведено теоретичні та експериментальні дослідження рідкокристалічних комірок для управління поляризаціею випромінювання лазера. Для нематичних плоских рідкокристалічних комірок існуе напруга відсічення, яка становить 2,2-2,5 В для комірки, описаної в даній роботі. При вивченні взаемодії лазерного випромінювання з коміркою було виявлено, що кут оріентації поляризації в просторі змінюеться від 0 до $90^{\circ}$ при прикладенні напруги від 2,2 до 10 В. При прикладенні напруги більше 10 В, комірка «насичуеться», і кут повороту поляризації змінюеться дуже мало, при прикладенні напруги більше 10 В може відбутися електричний пробій рідкокристалічного шару. Проведено теоретичне моделювання синхронізації мод в кільцевому волоконному лазері. А саме, було вивчено формування вихідних лазерних імпульсів при різних положеннях хвильових пластин або подачі напруги на рідкокристалічну комірку. Теоретично лазер може генерувати як безперервному, так і квазіімпульсному режимі. Створено експериментальний зразок волоконного лазера з синхронізацією мод за допомого рідкокристалічних комірок, який має наступні параметри: тривалість імпульсу фемтосекундного порядку, довжина хвилі випромінювання 1550 нм. Ці параметри дають перевагу при використанні лазера для високошвидкісної передачі даних по оптоволоконних лініях зв'язку і квантової криптографії.

Ключові слова: Волоконний лазер, Оптичне волокно, Фемтосекунда, Поляризація, Тривалість імпульсу, Амплітуда, Частота, Фаза. 